\title{
Balanced nutrition increases yield of pearl millet under drought
}

\author{
Rajneet K. Uppal*, Suhas P. Wani, Kaushal K. Garg, G. Alagarswamy \\ ICRISAT Development Centre, International Crops Research Institute for the Semi-Arid Tropics, Patancheru 502324, India
}

\section{A R T I C L E I N F O}

\section{Article history:}

Received 27 December 2013

Received in revised form 7 May 2014

Accepted 6 March 2015

\section{Keywords:}

Climate change

Nitrogen use efficiency

Resilience

Rainfed agriculture

Fertilizer

\begin{abstract}
A B S T R A C T
Improving the climate resilience of crops is particularly important in the semi-arid tropics (SAT) where variability and uncertainty of precipitation is expected to increase under climate change with detrimental impacts on the vulnerability of livelihoods of small farm holders. This study analyses a long-term strategic experiment datasets from fifteen experiments (1981-1995) managed under different fertility levels at International Crops Research Institute for the Semi-Arid Tropics (ICRISAT), Patancheru and on-farm balanced nutrition management trials (2010-2012) in Karnataka, India to evaluate the pearl millet performance in contrasting seasons with improved agronomic management. Long-term climate variability and yield trends were analyzed using ICRISAT's weather datasets. On-farm data analysis revealed that majority of farmers' field soils were deficient in organic carbon, available phosphorous, sulphur, zinc and boron at all the locations studied. Pearl millet grain yield and above ground dry matter was improved significantly with balanced nutrient application $(N P K+S+Z n+B)$ in farmers' field which were critically deficient in the soil nutrients. Even in comparatively drier years, application of balanced nutrient significantly increased grain yield and aboveground dry matter which provides resilience against drought through enhanced water productivity. Long-term experiments conducted in ICRISAT showed that nitrogen application increased grain yield and above ground dry matter in pearl millet however seasonal variability had a greater effect on yield than cultivars and applied N. Pearl millet yield was positively associated with August maximum temperature and negatively with seasonal precipitation. September precipitation $>125 \mathrm{~mm}$ which coincided with grain filling stage reduced grain yield. Benefit:cost analysis showed that balanced nutrient application of pearl millet is an economically sustainable option across the seasons. Pearl millet can be an important component of climate resilient agriculture in low production environments when managed with improved agronomic practices.
\end{abstract}

(c) 2015 Elsevier B.V. All rights reserved.

\section{Introduction}

Pearl millet (Pennisetum glaucum L.) is most widely grown type of millet and an important food and forage crop in Africa and Asia. Pearl millet has an ability to offset the effects of severe water and nutrient stress firstly by being able to withstand high temperatures (Ong, 1983) and by having sensitive and adaptive tillering capability (Ong and Monteith, 1985; Singh et al., 1998). The tillering ability can effectively restart growth after long periods of drought by producing new tillers which can at least mature to harvestable grain. Therefore, pearl millet is traditionally a component of the dryland systems grown on marginal soils which receive $150-750 \mathrm{~mm}$ of precipitation per year. Its importance is expected to increase under climate change scenarios for developing resilient cropping systems

\footnotetext{
* Corresponding author. Current address: NSW Department of Primary Industries, Wagga Wagga Agricultural Institute, Wagga Wagga, NSW 2650, Australia.

E-mail address: rajneet.uppal@dpi.nsw.gov.au (R.K. Uppal).
}

because of its suitability to the extreme limits of hot and dry climate.

Pearl millet has genetic variability for various morphological traits, yield components, adaptation and quality traits from the local landraces to hybrids that offer a wide range in plant-type from low- to high-tillering habit to early- and medium-duration cultivars (Bidinger et al., 1994). It is believed that hybrids require more $\mathrm{N}$ fertilizer compared to local landraces because their yields are generally higher (Joshi and Kalla, 1986). However, the response of different varieties to $\mathrm{N}$ fertilizer is variable over the years as grain yields may increase or decrease (O'Leary et al., 2008). And also crop responses to $\mathrm{N}$ depend on many factors, but particularly on yield potential and availability of residual soil $\mathrm{N}$, water and other nutrients (S, Zn, B). Therefore response of pearl millet for grain varies widely among $\mathrm{N}$ studies with optimum rates from 0 to greater than $150 \mathrm{~kg} \mathrm{ha}^{-1} \mathrm{~N}$ (Gascho et al., 1995). It is claimed that the high-yielding varieties and hybrids use nitrogen more efficiently (Wani et al., 1990). Based on the response to nitrogen application, it is estimated that for every $1 \mathrm{~kg} \mathrm{~N}$ applied, the hybrids 
or improved varieties return $10-15 \mathrm{~kg}$ of grain at $30-60 \mathrm{~kg} \mathrm{ha}^{-1} \mathrm{~N}$ (Maman et al., 1999). However, $40 \mathrm{~kg} \mathrm{ha}^{-1} \mathrm{~N}$ was found to be profitable for most of the pearl millet growing regions, but higher nitrogen levels (60-80 $\mathrm{kg} \mathrm{ha}^{-1}$ ) are recommended in areas with assured precipitation such as Gujarat and Uttar Pradesh. Much less is known, however concerning the effects on nitrogen use efficiency (NUE) and its components in pearl millet. Genotypic differences in $\mathrm{N}$ uptake and utilization have been found in many cereals e.g. wheat (Cox et al., 1985; Gooding et al., 2012a), corn (Chevalier and Schrader, 1977), and sorghum (Maranville et al., 1980). There is clear requirement to understand and harness genetic effects to improve NUE in pearl millet especially in SAT areas where farmers are resource poor and fertilizer availability is a concern. Genotypic diversity for grain yield and nitrogen use efficiency in pearl millet have been reported by Wani et al. (1990). However, contribution of uptake and utilization efficiency to overall nitrogen use efficiency have not been reported earlier.

A large yield gap exist between farmers practice and attainable yield of crops in SAT because of inappropriate crop, soil and water management at farm level, combined with persistent land degradation. Crop yields in SAT are sub-optimal and 5 folds lower than researchers field (Wani et al., 2009) because high spatial and temporal precipitation variability is coupled with poor nutrient status in the soils (Wani et al., 2009, 2011, 2012; Saharawat and Wani, 2013). Pearl millet is grown in such soils, generally without the application of fertilizer $\mathrm{N}$ and micronutrients. However little attention has been paid to importance of soil test based balanced nutrition $(\mathrm{NPK}+\mathrm{S}+\mathrm{Zn}+\mathrm{B})$ of pearl millet in SAT. Plant nutrients have interdependent metabolism within the plant system; uptake of nutrients is affected even if one nutrient is limiting. Nitrogen assimilation is affected with sulphur deficiency (Zhao et al., 1999) and $\mathrm{S}$ application is necessary to achieve maximum efficiency of applied $\mathrm{N}$ fertilizers (Fazli et al., 2008). Proper N fertilization and $\mathrm{Zn}$ application also has positive effect on grain $\mathrm{Zn}$ concentration (Gooding et al., 2012b; Cakmak et al., 2010) whereas excessive phosphorous interferes with $\mathrm{Zn}$ uptake and induces $\mathrm{Zn}$ deficiency (Mousavi, 2011). Phosphorous application can improve water use efficiency of crops under limited moisture conditions (Pyne et al., 1992). It is now well documented that wide range of SAT soils are deficient in micronutrients (Sahrawat et al., 2013) therefore it is important to promote soil test based nutrient management for judicious use of resources and to enhance fertilizer use efficiency.

As the frequency of extreme climatic events has increased (IPCC, 2007), it is important to evaluate the crops for their resilience against fragile environments as well as sustaining yields and soil fertility with better water and nutrient management. Longterm experiments in ICRISAT reveal that with appropriate land, water and nutrient management crop productivity increase as well soil quality improves along with increased Carbon sequestration of $330 \mathrm{kgCha}^{-1}$ year $^{-1}$ (Wani et al., 2009). Here, the purpose of balanced nutrient management in farmers' field is to harness the attainable yield potential of crops, reduce the injudicious use of fertilizers leading to environmental and soil degradation and improving livelihoods. Therefore, the objectives of this study were to compare the performance of pearl millet with balanced nutrition management against current farmers practice in contrasting seasons. Secondly, a meta-analysis of fifteen years unpublished data (ICRISAT) for four pearl millet cultivars to determine the response of genotypes to $\mathrm{N}$ fertilizer rates and quantify the effect of seasonal variations on pearl millet yield. The overall aim of this paper is to evaluate the effect of balanced nutrient management to bridge the existing yield gaps through enhanced productivity on farmers' fields and explore the possibility of genotypic variability for nitrogen use efficiency in pearl millet.

\section{Materials and methods}

\subsection{On-station trial}

\subsubsection{Crop husbandry and experimental design}

Fifteen field experiments conducted between 1981 and 1995 compared the performance of four genotypes of Pearl millet under different fertility regimes. All experiments were conducted on the same site at the ICRISAT centre, Patancheru (near Hyderabad), India (17.5N, 78.5E, $545 \mathrm{~m}$ altitude) on an Alfisol which are characterized by $\mathrm{N}$ and $\mathrm{P}$ deficiency, coupled with low organic matter. Before initiating the experiment soil $(0-500 \mathrm{~mm})$ was tested for soil textural, chemical and water retention properties (Table 1 ). The experiment was a split plot design with four replications; genotypes as main plot and $\mathrm{N}$ fertilizer levels as sub plots. Fertilizer treatments included: no $\mathrm{N}$ application, $20 \mathrm{~kg} \mathrm{Nha}^{-1}$ as urea $+9 \mathrm{~kg} \mathrm{P}_{2} \mathrm{O}_{5} \mathrm{ha}^{-1}$ as single super phosphate, $40 \mathrm{~kg} \mathrm{~N} \mathrm{ha}^{-1}+18 \mathrm{~kg} \mathrm{P}_{2} \mathrm{O}_{5}$ ha $^{-1}$ were broadcasted as basal dressings. Untreated seeds were drilled on a single day within each year between end of June to first fortnight of July at a depth of $50 \mathrm{~mm}$, with a row spacing of $0.75 \mathrm{~m}$ and plant spacing of $0.1 \mathrm{~m}$. Weeding and intercultural operations were undertaken as and when required. Crop was harvested in the last week of September. Weather data was recorded at automated meteorological station at the site.

\subsubsection{Plant material}

GAM 73 is dwarf elite line from Senegal and a source of major d2 dwarfing gene (Rai and Rao, 1991). The d2 dwarfing gene has been extensively used to reduce plant height in high yielding pearl millet hybrids in the United States, India and Africa. Ex-Bornu is an important landrace population from the Bornu region of northeast Nigeria, which is extensively used as parental material in breeding programmes in India. Ex-Bornu is tall and matures in 90-95 days. 700256 was a tall African landrace and matures in 90-95 days. BJ 104 is most popular and widely cultivated pearl millet hybrid in India. BJ 104 is medium tall with good basal tillering, red nodal joints, medium long cylindrical ear heads and matures in 75-82 days.

\subsubsection{Agronomic assessments}

At harvest above ground plant samples were harvested. The panicles were separated and threshed. Fresh stover yield was recorded and a sub sample was collected and milled. The sub sample biomass and grain was dried at $70^{\circ} \mathrm{C}$ for $72 \mathrm{~h}$. Nitrogen concentration was determined for the vegetative tissues and grain samples using Technicon Auto analyser. The destructive samples allowed the interpretation of effects on grain $\mathrm{N}$ uptake in terms of above-ground crop $\mathrm{N}$ uptake and partitioning of $\mathrm{N}$ to developing grain from vegetative tissues (NHI)

\subsubsection{Nitrogen use efficiency calculations}

Nitrogen use efficiency (NUE) is defined as the ability of a crop to produce grain from available N (Moll et al., 1982; Kindred and Gooding, 2004). NUE can be derived by two components: first is the ability of the crop to take up nitrogen from the soil (nitrogen uptake efficiency; NUpE) and the second is the ability of the crop to produce grain from the nitrogen in the canopy, i.e. nitrogen utilization efficiency to produce grain (NUtEg). Nitrogen uptake efficiency can be expressed as the total amount of nitrogen in the above ground crop

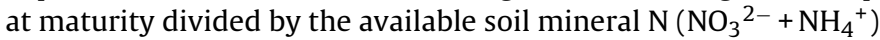
plus nitrogen applied as fertilizer. $\mathrm{N}$ utilization efficiency can be expressed as grain yield divided by total aboveground $\mathrm{N}$ uptake (Gooding et al., 2012a). The destructive plant samples allowed the calculation of NUpE of the above-ground crop; the $\mathrm{N}$ utilization efficiency to produce grain (NUtE). 
Table 1

Major soil characteristics of the experimental site at ICRISAT, Patancheru.

\begin{tabular}{|c|c|c|c|c|c|c|c|c|c|}
\hline \multirow[t]{3}{*}{ Depth (mm) } & \multicolumn{3}{|c|}{ Size class and particle diameter (mm) } & \multirow[t]{3}{*}{$\mathrm{pH}(1: 2.5) \mathrm{H}_{2} \mathrm{O}$} & \multirow[t]{3}{*}{ EC (1: 2.5) suspension } & \multirow[t]{3}{*}{ OC (\%) } & \multirow[t]{3}{*}{$\mathrm{N}$ ppm } & \multicolumn{2}{|c|}{ Water retention } \\
\hline & Sand (2.0-0.02) & Silt (0.02-0.002) & Clay $(<0.002)$ & & & & & 1/3-bar & 15 bar \\
\hline & \multicolumn{3}{|c|}{ (\% of $2 \mathrm{~mm}$ soil particle) } & & & & & \multicolumn{2}{|c|}{ Gravimetric \% } \\
\hline $0-50$ & 79.3 & 6.4 & 14.3 & 6.0 & 0.1 & 0.55 & - & 16.2 & 6.3 \\
\hline $50-200$ & 66.7 & 5.5 & 27.8 & 6.9 & 0.1 & 0.52 & 343 & 20 & 12.4 \\
\hline $200-500$ & 41.6 & 6.8 & 51.6 & 6.9 & 0.1 & 0.63 & 455 & 21.9 & 13.9 \\
\hline
\end{tabular}

\subsubsection{Field water balance and crop water productivity}

Field scale hydrology for the experimental site was analyzed using one-dimensional water balance model called as Water Impact Calculator (WIC) developed by ICRISAT. WIC requires soil (water retention and soil depth), weather (ET $\mathrm{E}_{0}$ and precipitation), crop growth [biomass $\left(K_{c}\right)$ and root growth function], topography (land slope, land form conditions), and crop management (date of crop sowing and harvesting) details as an input to the model. WIC was well calibrated and validated with different soil types, land use and cropping system using different water balance components (surface runoff and soil moisture) measured at ICRISAT and on-farm trials before applying to the present data set (Garg et al., 2013).

In WIC, evaporation and transpiration values are estimated based on imposed surface boundary conditions (atmospheric boundary with rainfed condition) and moisture accessibility between surface soil layer and root zone. Water available in top $10 \mathrm{~cm}$ layer is contributed in satisfying the evaporation demand whereas; moisture available within root zone is used to meet crop water demand. Crop water requirement (CWR) for a given crop is calculated such as:

Crop water requirement $\mathrm{day}=i=\left[K_{c}\right]_{\mathrm{day}=i} \times\left[\mathrm{ET}_{0}\right]_{\mathrm{day}=i}$

if : $\sum_{j=1}^{\text {rootzone }}$ Available water > Crop water requirements;

$\mathrm{ET}_{\mathrm{day}=i}=$ Crop water requirements

otherwise $\mathrm{ET}_{\mathrm{day}=i}=\sum_{j=1}^{\text {rootzone }}$ Available water

where $i$ denotes days after sowing; $j$ symbolize each $\mathrm{cm}$ increment in soil layer reaching up to root zone; and $K_{c}$ is the crop coefficient. Root zone depth is dynamic variable and controlled by crop growth stage (days after sowing) as defined by Allen et al. (2005). It was assumed that evaporation from soil surface was inversely proportional to vegetative growth/stage. Thus, after achieving full vegetative crop growth $\left(K_{c} \geq 1.0\right)$, evaporation from the soil surface was considered almost negligible. If moisture in root zone was not sufficient to meet crop water requirement, then WIC counted crop under water stress. With given precipitation and land management, number of days crop experienced water stress was estimated in different years as shown in Eq. (3).

Crop water stress $(-)=1-\frac{\text { Actual ET }}{\text { ET under nonlimiting water condition }}$

For further analysis, we divided entire study period into three broad category (dry, normal and wet years) based on precipitation received during crop season (25 June-23 September). According to the Indian Meteorological Department, Pune, India (http://www.imdpune.gov.in) precipitation that was $20 \%$ lower than mean (precipitation $<530 \mathrm{~mm}$ ) was considered as dry or deficit year; precipitation between $+20 \%$ and $-20 \%$ ( $530<$ precipitation $<640 \mathrm{~mm}$ ) as normal year and precipitation greater than $20 \%$ (precipitation $>640 \mathrm{~mm}$ ) as wet year.

Crop Water Productivity (WP) is the amount of grain yield obtained per unit of water consumption (Tuong and Bouman, 2003; Garg et al., 2012). Depending on the type of water sources considered, WP is expressed as grain yield per unit water evapotranspired $\left(\mathrm{WP}_{\mathrm{ET}}\right)$. In this study, WP is calculated using simulated values of consumptive water use $\left(\mathrm{ET}_{\mathrm{a}}\right)$ and measured crop yield in different years.

$\mathrm{WP}_{\mathrm{ET}}\left(\mathrm{kg} \mathrm{m}^{-3}\right)=\frac{\text { Grain yields }(\mathrm{kg})}{\text { Consumptive water use }\left(\mathrm{ET} \text { in } \mathrm{m}^{3}\right)}$

\subsection{On-farm trials}

The data resulted from a series of trials conducted in 30 districts across Karnataka to assess the effect of soil test based balanced nutrient application on major crops on small holder farms under Bhoochetana initiative by Government of Karnataka and ICRISAT to enhance the productivity in rainfed agriculture. For this paper, results from pearl millet farmers' field trials during cropping seasons 2010-2012 are presented.

Table 2

Chemical properties of soil samples collected from farmer's field at different locations in Karnataka. Figures in parentheses are percent deficient fields.

\begin{tabular}{|c|c|c|c|c|c|c|c|c|c|}
\hline District & $\mathrm{pH}$ & $\begin{array}{l}\text { EC } \\
\mathrm{dS} / \mathrm{m}\end{array}$ & $\begin{array}{l}\text { OC } \\
\%\end{array}$ & $\begin{array}{l}\text { Av P } \\
\text { ppm }\end{array}$ & $\begin{array}{l}\text { Av K } \\
\text { ppm }\end{array}$ & $\begin{array}{l}\text { Av S } \\
\text { ppm }\end{array}$ & $\begin{array}{l}\text { Av Zn } \\
\text { ppm }\end{array}$ & $\begin{array}{l}\text { Av B } \\
\text { ppm }\end{array}$ & No. of samples \\
\hline Bagalkot & 7.8 & 0.35 & $\begin{array}{l}0.62 \\
(36)\end{array}$ & $\begin{array}{l}2.3 \\
(97)\end{array}$ & $\begin{array}{l}60 \\
(28)\end{array}$ & $\begin{array}{l}11.7 \\
(59)\end{array}$ & $\begin{array}{l}0.9 \\
(55)\end{array}$ & $\begin{array}{l}0.7 \\
(69)\end{array}$ & 2440 \\
\hline Bellary & 7.4 & 0.40 & $\begin{array}{l}0.63 \\
(32)\end{array}$ & $\begin{array}{l}2.9 \\
(90)\end{array}$ & $\begin{array}{l}55 \\
(33)\end{array}$ & $\begin{array}{l}11.1 \\
(67)\end{array}$ & $\begin{array}{l}1.3 \\
(19)\end{array}$ & $\begin{array}{l}1.2 \\
(36)\end{array}$ & 2100 \\
\hline Bijapur & 8.3 & 0.40 & $\begin{array}{l}0.42 \\
(70)\end{array}$ & $\begin{array}{l}3.8 \\
(81)\end{array}$ & $\begin{array}{l}209 \\
(3)\end{array}$ & $\begin{array}{l}24.4 \\
(77)\end{array}$ & $\begin{array}{l}0.5 \\
(89)\end{array}$ & $\begin{array}{l}0.9 \\
(43)\end{array}$ & 2791 \\
\hline Gulbarga & 8.0 & 0.36 & $\begin{array}{l}0.47 \\
(64)\end{array}$ & $\begin{array}{l}5.0 \\
(70)\end{array}$ & $\begin{array}{l}257 \\
(0)\end{array}$ & $\begin{array}{l}39.4 \\
(75)\end{array}$ & $\begin{array}{l}0.5 \\
(86)\end{array}$ & $\begin{array}{l}0.7 \\
(68)\end{array}$ & 3633 \\
\hline Koppal & 7.7 & 0.26 & $\begin{array}{l}0.45 \\
(65)\end{array}$ & $\begin{array}{l}19.6 \\
(7)\end{array}$ & $\begin{array}{l}147 \\
(2)\end{array}$ & $\begin{array}{l}82.5 \\
(22)\end{array}$ & $\begin{array}{l}0.8 \\
(59)\end{array}$ & $\begin{array}{l}0.3 \\
(87)\end{array}$ & 2499 \\
\hline Raichur & 8.2 & 0.60 & $\begin{array}{l}0.42 \\
(71)\end{array}$ & $\begin{array}{l}11.1 \\
(48)\end{array}$ & $\begin{array}{l}202 \\
(4)\end{array}$ & $\begin{array}{l}145 \\
(64)\end{array}$ & $\begin{array}{l}0.7 \\
(79)\end{array}$ & $\begin{array}{l}1.2 \\
(39)\end{array}$ & 3343 \\
\hline Yadgir & 8.0 & 0.38 & $\begin{array}{l}0.40 \\
(75)\end{array}$ & $\begin{array}{l}10.2 \\
(41)\end{array}$ & $\begin{array}{l}191 \\
(4)\end{array}$ & $\begin{array}{l}31.6 \\
(65)\end{array}$ & $\begin{array}{l}0.6 \\
(86)\end{array}$ & $\begin{array}{l}0.7 \\
(57)\end{array}$ & 1982 \\
\hline
\end{tabular}




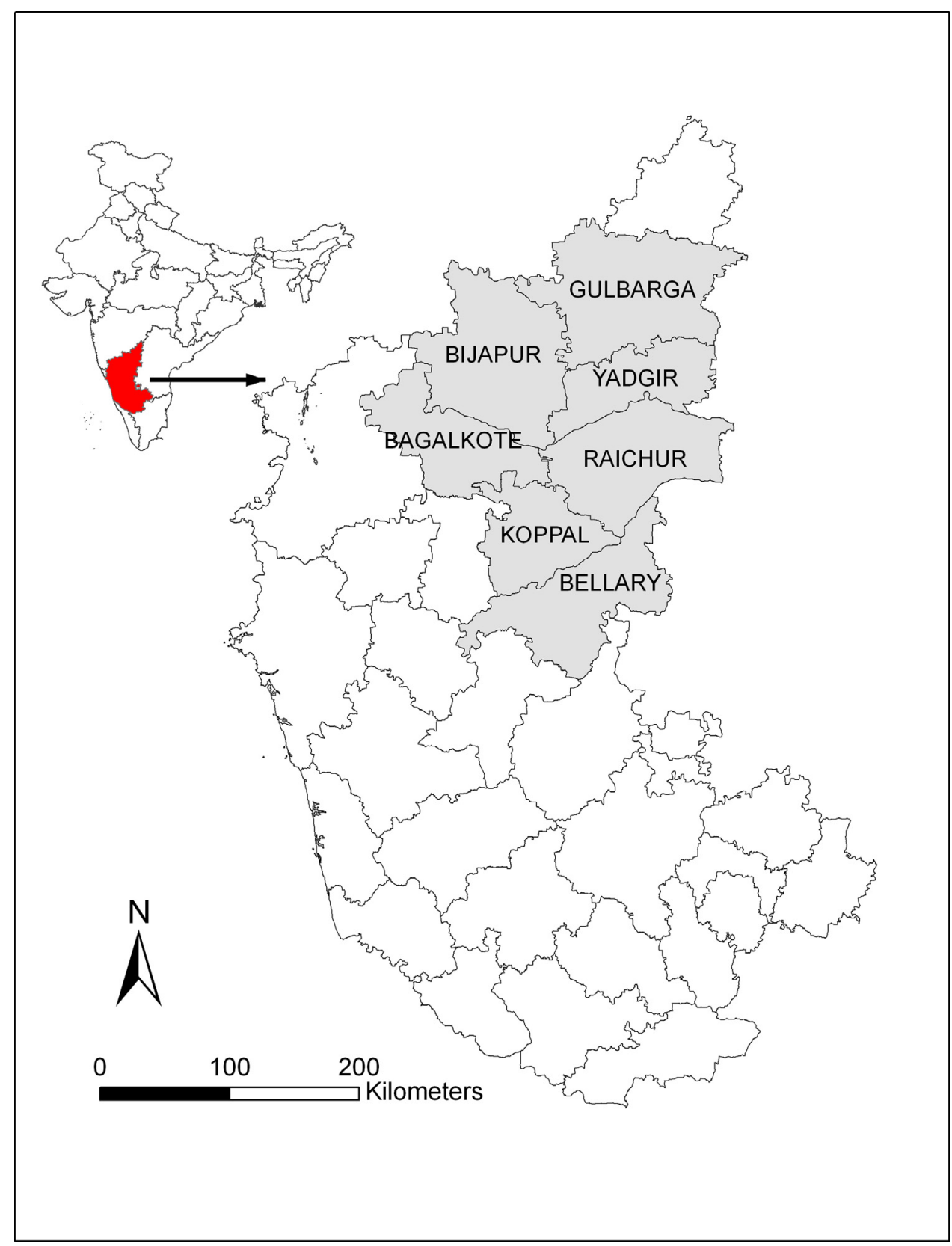

Fig. 1. Study sites for farmers' field trials in seven districts of Karnataka, India.

During cropping seasons 2010-2012, a number of farmer's field trials were conducted in seven districts of Karnataka representing three agro ecological zones; Northern dry (Bagalkot, Bijapur, Bellary, Koppal, Raichur), North Eastern transition (Gulbarga) and North eastern dry zone (Yadgir) (Fig. 1). Soil samples (0-150 mm) were collected from farmer's field using stratified random soil sampling method considering soil types including topography, major crops and land holding size (Sahrawat et al., 2013). Soil samples were analyzed for different chemical properties in the Central Analytical Services Laboratory, ICRISAT (Table 2). Based on the total soil samples analyzed in the district, percent deficient field in the district were calculated. Earlier in Karnataka, Blanket fertilizer recommendations involve only application of major nutrients $(\mathrm{N}, \mathrm{P}$ and $\mathrm{K}$ ) and completely ignoring secondary and micro nutrients $(\mathrm{S}$, $\mathrm{B}$ and $\mathrm{Zn}$ ) which rarely match soil nutrient demand. Fertilizer recommendations were formulated based on the fertility status of the soil and crop requirement. A full dose of nutrient was applied when
Table 3

Seasonal rainfall (mm) during crop season (July to September) at different locations in Karnataka where farmers' field trials were conducted.

\begin{tabular}{lllll}
\hline District & 2010 & 2011 & 2012 & $\begin{array}{l}\text { Long-term } \\
\text { average }\end{array}$ \\
\hline Bagalkot & 450 & 335 & 216 & 360 \\
Bellary & 469 & 260 & 205 & 387 \\
Bijapur & 507 & 307 & 272 & 428 \\
Koppal & 508 & 304 & 226 & 383 \\
Raichur & 633 & 356 & 289 & 479 \\
Yadgir & 736 & 477 & 394 & 590 \\
Gulbarga & 754 & 514 & 437 & 640 \\
\hline
\end{tabular}

$>50$ percent deficient and a half dose was applied if deficiency was less than 50 percent. Seasonal precipitation during crop season is presented in Table 3.

In each village 20 farmers were selected for conducting on-farm participatory demonstration trials. Each field was divided into two 
plots each covering an area of $1000-2000 \mathrm{~m}^{2}$ with two treatments: (1) Farmer's practice (FP), (2) Improved practice (IP) consisting of application of balanced nutrients based on soil analysis. Farmer's crop, variety and crop management practices were all same in both the treatments such that each farmer was considered as replication. Farmers used improved cultivar 86M86 and Kaveri Boss which were popular among the all regions. Before sowing, seeds were treated with Captan @ $1.5 \mathrm{~g} \mathrm{~kg}^{-1}$ seed and $4 \mathrm{~kg} \mathrm{ha}^{-1}$ seed was used to maintain a population of 220,000 plants ha $^{-1}$ at a row spacing of $450 \mathrm{~mm}$ and a plant spacing of $90 \mathrm{~mm}$. All plots were seeded on the same day after the first effective rain in each year. Half dose of $\mathrm{N}$ and all other nutrients were broadcasted at the time of sowing whereas second dose of $\mathrm{N}$ was applied at 40 days after sowing. These plots were maintained throughout the cropping season and were managed by the farmer with support from research technicians providing recommendations on management of plots.

At physiological maturity, crops were harvested from three samples per plot each of $9 \mathrm{~m}^{2}$ areas from both the treatments. The harvest area was chosen at random but representative of the plot was used to extrapolate yields to an area basis. A subsample was taken out to calculate grain yield that was then calculated on hectare basis at $12 \%$ moisture. Aboveground crop biomass was weighed at harvest and subsamples were dried at $80^{\circ} \mathrm{C}$ for $48 \mathrm{~h}$ for final dry weight.

Benefit cost ratio were calculated based on additional cost and additional returns with application of micronutrients as other inputs in both the treatments were same. Hence, additional cost on fertilizer application was worked based on prevailing market prices of fertilizers e.g. Indian Rupee (INR) $29 \mathrm{~kg}^{-1}$ zinc sulphate, INR $120 \mathrm{~kg}^{-1}$ agribor and INR $2 \mathrm{~kg}^{-1}$ gypsum. Additional returns were estimated based on minimum support price each year.

\subsection{Statistical analysis}

Genstat 14 was used for ANOVA to investigate main effects and interactions between genotype and $\mathrm{N}$ levels using the treatment structure as Genotype $\times \mathrm{N}$ Level and the blocking as Year/block/N level/genotype. This analysis revealed significant interactions between genotype and $\mathrm{N}$ level. Analyses using all Years and Genotypes were therefore analyzed with the treatment structure of Year $\times$ Genotype. For farmer's field trials, Analysis of residual maximum likelihood (REML) used the data sets encompassing all years and comprised a fixed model of location $\times$ practice, and a random model of farmer.

\section{Results}

\subsection{On-station trials}

Long term precipitation trends have been earlier studied for the location by Rao and Wani (2011) which indicate that annual precipitation at the location did not change much however distribution of precipitation across the seasons varies.

Seasonal precipitation during crop cycle (June-September) showed large inter-annual variability (CV=28\%) (Fig. 2). Distribution of precipitation across each growing season was not uniform e.g. relatively dry seasons in 1984, 1985, 1986 and 1987 and high precipitation events were recorded during the month of September in growing seasons 1981, 1983, 1988 and 1989 which coincided with flowering and grain filling. There was also an exceptional decline in June maximum and minimum temperature both during growing season 1985 and 1990.

\subsubsection{Effect of season on pearl millet}

Pearl millet yields were highly variable from year to year with no clear trend over time (Fig. 3). Grain yield ranged from $0.6 \mathrm{tha}^{-1}$
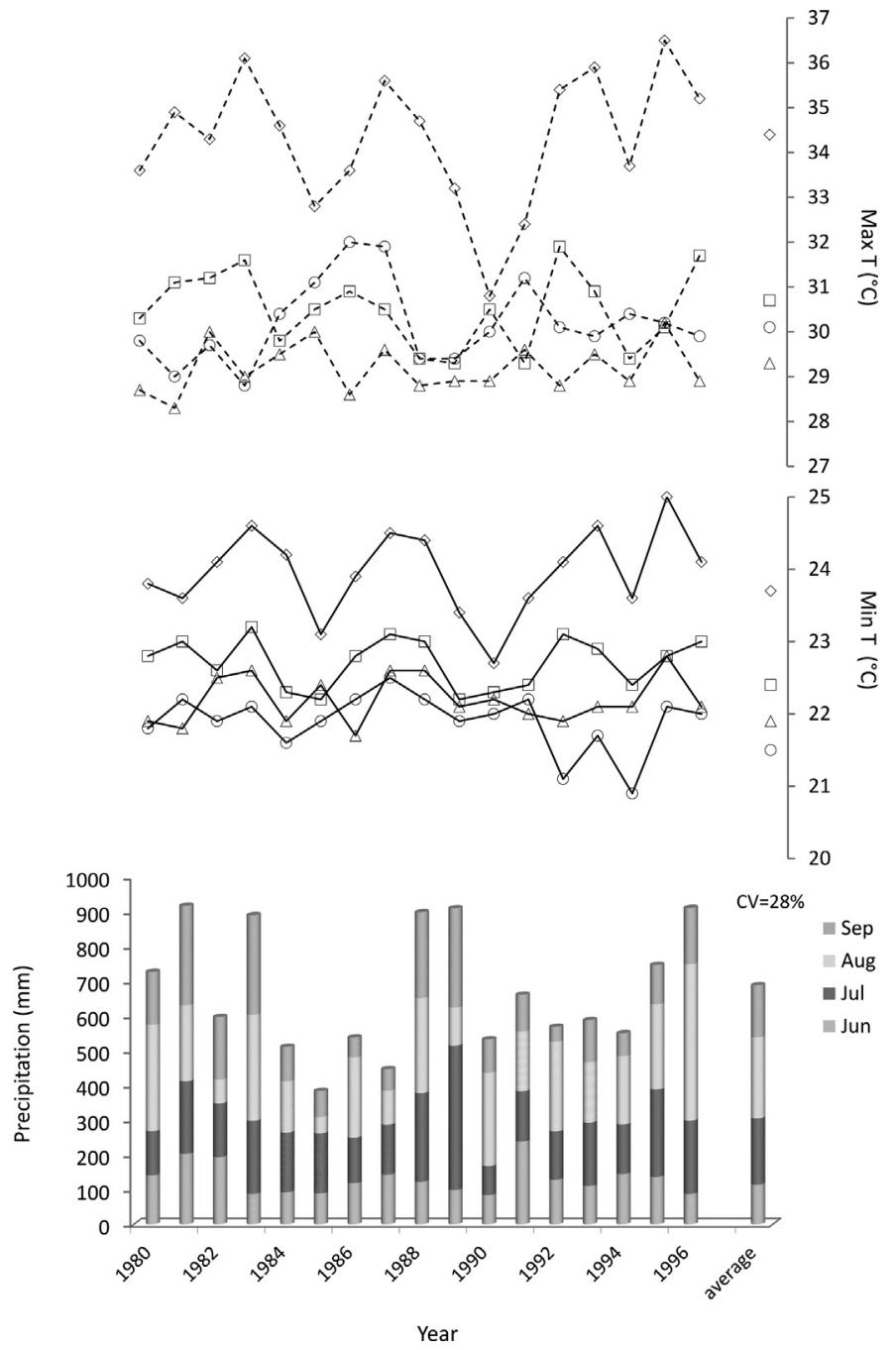

Fig. 2. Monthly weather data at the experimental site. (a), (b) Maximum and minimum temperature for June $(\diamond)$, July $(\square)$, August $(\triangle)$ and September $(\bigcirc)$. (c) Precipitation from June to September. Average corresponds to long-term averages (40 years) at the location.

to 2.5 tha $^{-1}$ however ranking of genotypes for grain yield was not consistent across the seasons resulting in year-cultivar interaction. For example GAM 73 had significantly high yields in growing season 1993-95; otherwise it was lowest yielding genotype. Secondly BJ 104 had exceptionally higher yield in 1985. Ex-Bornu had significant higher aboveground dry matter production across the seasons. Crude protein (CP) levels increased over the years.

Seasonal grain yield variability can be explained by weather parameters as suggested by regression analysis. There was not a significant effect of August minimum temperature (Anthesis and grain filling) on grain yield however; a significantly positive linear relationship of August maximum temperature with grain yield was reported $(P<0.05)$ (Fig. 4 a and b). Grain yield had significant negative relation with seasonal precipitation and this effect can be more precisely explained by September precipitation which coincided with flowering and grain filling (Fig. 4c and d). Quadratic fits for grain yield and September precipitation appeared appropriate and it was negative and highly significant $(P<0.05)$.

Out of fifteen growing seasons, five dry years (deficit), six normal and four wet years were reported (Table 4). Model partitioned precipitation into principle hydrological components such as ET, surface runoff and deep percolation based on water balance approach. Out of total precipitation received during crop period, ET 

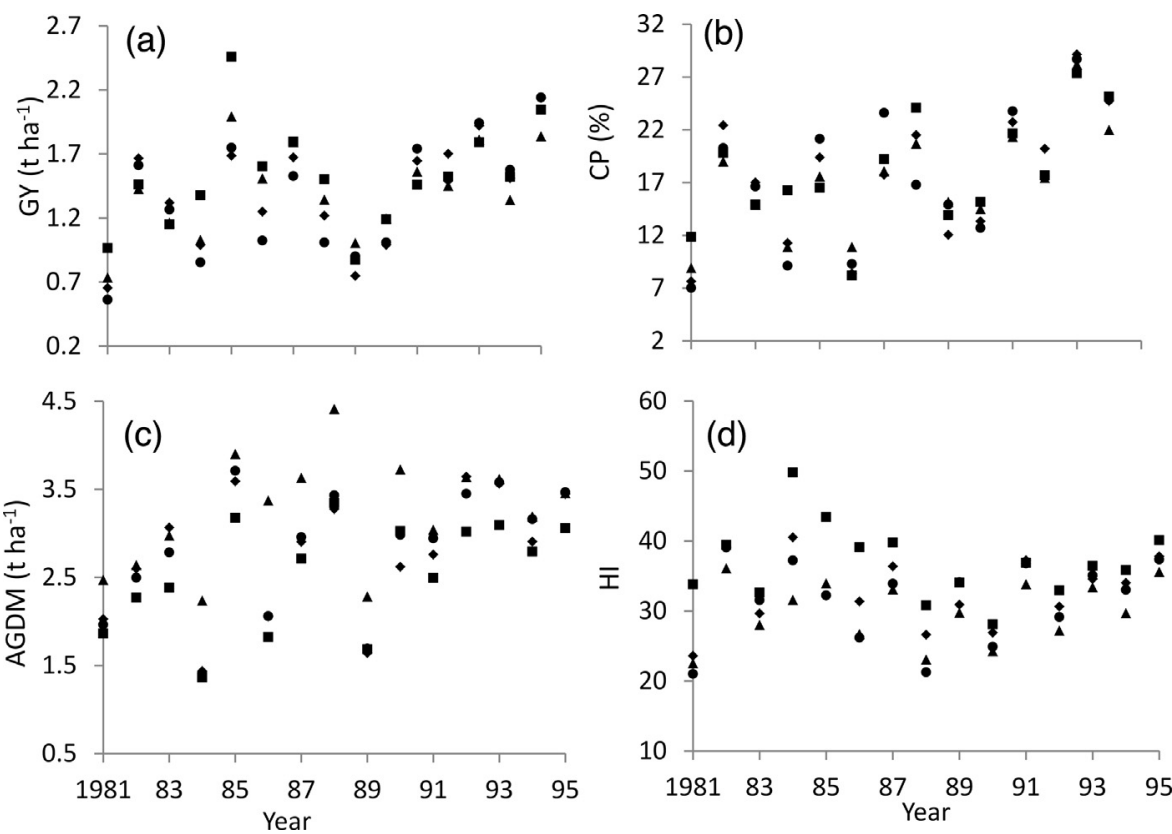

Fig. 3. Grain yield, above ground dry matter (AGDM), crude protein and HI of pearl millet in study period. Symbols represents cultivar means over N rates ( $) 700256$, ( BJ 104, (ム) Ex-Bornu and (•) GAM 73.

Table 4

Water balance components, average crop yield and water productivity of long-term experiment during dry, normal and wet years (data from 1981 and 1995).

\begin{tabular}{|c|c|c|c|c|c|c|c|}
\hline Category & $\begin{array}{l}\text { Total no. of } \\
\text { years }\end{array}$ & Rainfall (mm) & $\mathrm{ET}(\mathrm{mm})$ & $\begin{array}{l}\text { Surface } \\
\text { runoff }+ \text { percolation } \\
(\mathrm{mm})\end{array}$ & $\begin{array}{l}\text { Millet grain } \\
\text { yield }\left(\mathrm{kg} \mathrm{ha}^{-1}\right)\end{array}$ & $\begin{array}{l}\text { Crop water } \\
\text { stress (\%) }\end{array}$ & $\mathrm{WP}_{\mathrm{ET}}\left(\mathrm{kg} \mathrm{m}^{-3}\right)$ \\
\hline Dry & 5 & 380 & 228 & 152 & $1505 \pm 297$ & 30 & 0.66 \\
\hline Normal & 6 & 499 & 250 & 249 & $1607 \pm 424$ & 25 & 0.64 \\
\hline Wet & 4 & 771 & 273 & 498 & $985 \pm 333$ & 14 & 0.36 \\
\hline
\end{tabular}

in dry, normal and wet years was found to be $60 \%, 50 \%$ and $35 \%$, respectively and remaining amount converted into surface runoff and deep percolation. Negative correlation of millet yield with seasonal precipitation was further explained by other hydrological components. Surplus precipitation in wet years generated excess runoff and waterlogged conditions which adversely affected crop yields as shown in Fig. 4e. On the other hand, positive trend was found between consumptive water use (ET) and pearl millet yield (Fig. 4f). Due to shallow soil depth $(30-50 \mathrm{~cm})$ and poor water holding capacity of experimental site, crop experienced water stress even in normal years. On the other hand, water stress was minimal in wet years (marked by circle in Fig. $4 \mathrm{~g}$ ) but yield declined due to excess precipitation. Wet spell analysis (five days rainfall of more than $30 \mathrm{~mm}$ ) showed a negative relationship between grain yield and number of wet days (Fig. $4 \mathrm{~h}$ ).

Millet yield in normal years was found maximum followed by dry and wet years. There was not a significant difference in crop yield between dry and normal year but yields in wet years were significantly low. Water productivity of millet crop $\left(\mathrm{WP}_{\mathrm{ET}}\right)$ was between 0.36 and $0.66 \mathrm{~kg} \mathrm{~m}^{-3}$ (Table 4 ). $\mathrm{WP}_{\mathrm{ET}}$ in dry year was almost double than the wet years.

\subsubsection{Effect of nitrogen on pearl millet}

When averaged across all seasons and cultivars, grain yield and AGDM was increased by $0.35 \mathrm{tha}^{-1}$ and $0.89 \mathrm{tha}^{-1}$, respectively with $40 \mathrm{~kg} \mathrm{ha}^{-1} \mathrm{~N}$ application. The interaction between $\mathrm{N}$ level and cultivar for individual years was significant. The metaanalysis over fifteen years showed a significant cultivar $\times \mathrm{N}$ level interaction for grain yield, aboveground dry matter, $\mathrm{HI}$ and crude protein which demonstrates that ranking of genotypes differs with nitrogen levels. BJ 104 and Ex-Bornu responded to higher $\mathrm{N}$ levels with increasing grain yields, AGDM and crude protein simultaneously (Table 5). All the genotypes increased AGDM with increase in $\mathrm{N}$ application rate however accumulation of AGDM was not partitioned to developing grain leading to lower $\mathrm{HI}$ and grain yield in Ex-Bornu, 700256 and GAM 73. There was no significant effect of $\mathrm{N}$ levels on HI. There was no effect of cultivar in CP however it was increased with $\mathrm{N}$ application.

Grain $\mathrm{N}$ uptake and total aboveground $\mathrm{N}$ uptake increased with increasing $\mathrm{N}$ level, however partitioning of $\mathrm{N}$ was not affected by $\mathrm{N}$ application. There was not a significant effect of cultivar on grain $\mathrm{N}$ uptake however, the ranking of genotypes varied with $\mathrm{N}$ level. Grain $\mathrm{N}$ uptake was significantly higher at $40 \mathrm{~kg} \mathrm{ha}^{-1} \mathrm{~N}$ level in $\mathrm{BJ} 104$ and Ex-Bornu however at $20 \mathrm{~kg} \mathrm{ha}^{-1}$, grain $\mathrm{N}$ uptake was similar in all cultivars (Table 6). Above ground $\mathrm{N}$ uptake was increased with increasing $\mathrm{N}$ rate and cultivar $\times \mathrm{N}$ level interaction was significant. Ex-Bornu had significantly higher aboveground $\mathrm{N}$ uptake at $40 \mathrm{~kg} \mathrm{ha}^{-1}$ however, lowest NHI at same N rate. BJ 104 had significantly higher NHI at all N rates. GAM 73 and 700256 achieved highest $\mathrm{N}$ partitioning at $20 \mathrm{~kg} \mathrm{~N}^{-1}$. Regression analysis suggested that grain $\mathrm{N}$ uptake is more closely associated with grain yield explaining 70 percent variation (Fig. 5a and b).

NUpE increased from 0.99 without fertilizer application to 1.30 under highest fertilizer rate. Averaging across $\mathrm{N}$ treatments, the linear regression of NUpE and NUE was not statistically significant (Fig. 5c). There was difference in NUpE amongst the cultivars in the range 0.84-1.09 under low $\mathrm{N}$ treatment and 1.06-1.62 under $40 \mathrm{~kg} \mathrm{Nha}^{-1}$ (Table 7). Overall NUtE increased from 11.38 under $40 \mathrm{~kg} \mathrm{~N} \mathrm{ha}^{-1}$ treatment to $18 \mathrm{~kg} \mathrm{DM} \mathrm{kg}^{-1} \mathrm{~N}$ under low fertility conditions. Averaging across $\mathrm{N}$ treatments, there was a positive 

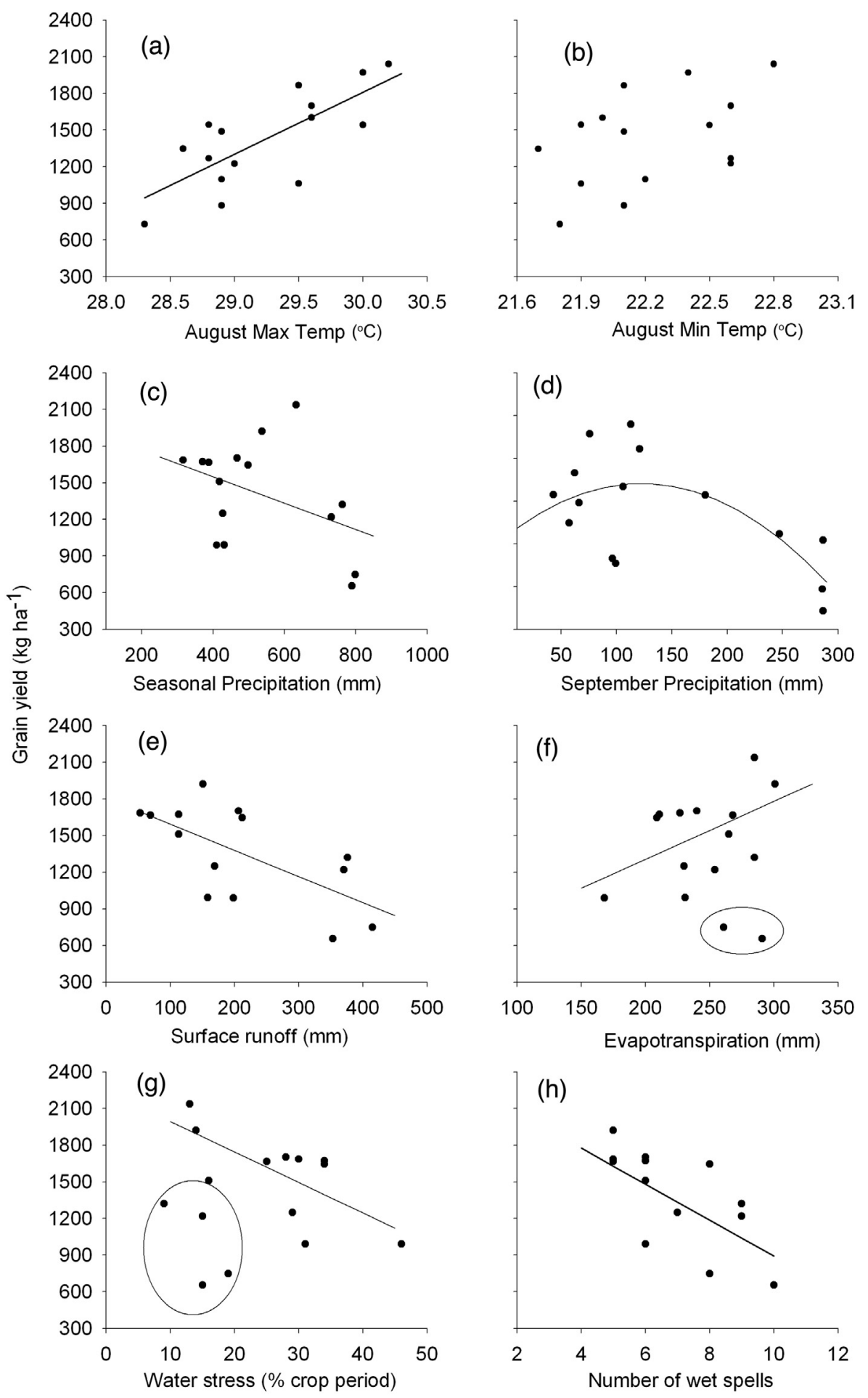

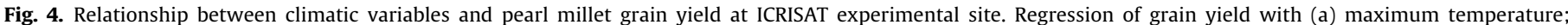

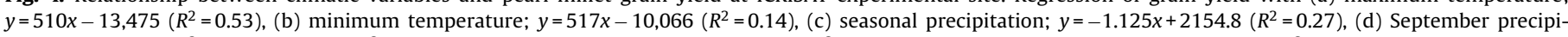

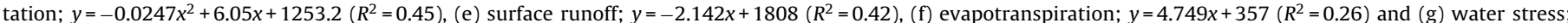
$y=-24.8 x+2238\left(R^{2}=0.47\right)$, and $(\mathrm{h})$ wet spell; $y=-147.4 x+2366\left(R^{2}=0.38\right)$.

linear relationship between NUtE and NUE amongst the cultivars accounting for 72 percent variation in NUE (Fig. 5d). There was a $\mathrm{N}$ treatment $\times$ cultivar interaction partly because of GAM 73 decreased NUtEg under $20 \mathrm{~kg} \mathrm{ha}^{-1}$ fertilizer treatment while increased in other $\mathrm{N}$ rates. NUE was increased in low fertility regime (16.5) compared to $40 \mathrm{~kg} \mathrm{~N} \mathrm{ha}^{-1}$ (12.4). The cultivars differed in NUE and the interaction between $\mathrm{N}$ treatment and cultivar was close to significant $(P=0.06)$. Agronomic efficiency to use nitrogen was affected by $\mathrm{N}$ level, however effect of cultivar and cultivar $\times \mathrm{N}$ level interaction were not significant. Agronomic efficiency decreased with increase in $\mathrm{N}$ application.

Year $\times \mathrm{N}$ level $\times$ cultivar interaction was significant $(<0.05)$ for all parameters, indicating that cultivar response to different fertility regimes differ between years. This may be attributed to variation 

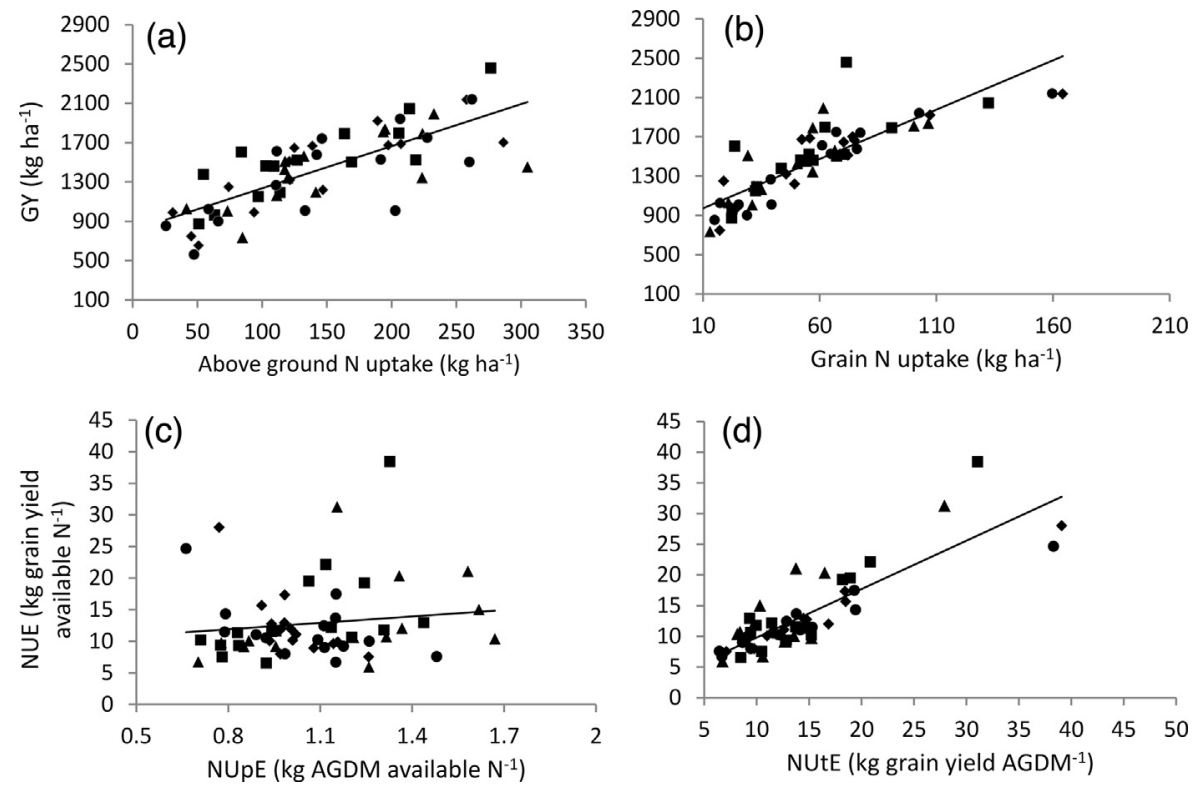

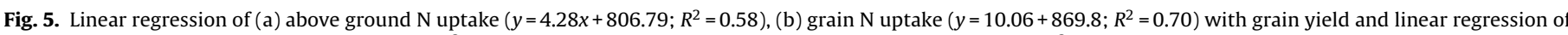

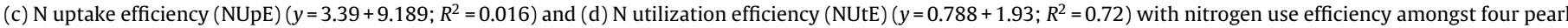

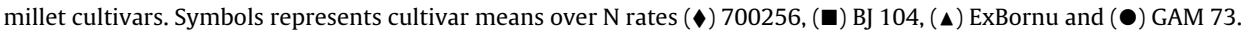

Table 5

Effect of $\mathrm{N}$ fertilizer rates on Grain yield (GY), above ground dry matter (AGDM), harvest index $(\mathrm{HI})$ and crude protein concentration $(\mathrm{CP})$ in pearl millet cultivars

\begin{tabular}{|c|c|c|c|}
\hline \multirow[t]{2}{*}{ Cultivar } & \multicolumn{3}{|c|}{$\mathrm{N}$ applied $\left(\mathrm{kg} \mathrm{ha}^{-1}\right)$} \\
\hline & 0 & 20 & 40 \\
\hline \multicolumn{4}{|l|}{ GY $\left(\right.$ tha $\left.\mathbf{a}^{-1}\right)$} \\
\hline 700256 & 1.25 & 1.16 & 1.37 \\
\hline BJ 104 & 1.28 & 1.33 & 1.71 \\
\hline EXBORNU & 1.07 & 1.33 & 1.62 \\
\hline GAM 73 & 1.06 & 1.20 & 1.36 \\
\hline SED & 0.059 & & \\
\hline \multicolumn{4}{|c|}{$\operatorname{AGDM}\left(\mathrm{tha}^{-1}\right)$} \\
\hline 700256 & 2.32 & 2.30 & 3.01 \\
\hline BJ 104 & 2.15 & 2.30 & 2.68 \\
\hline EXBORNU & 2.55 & 2.97 & 3.94 \\
\hline GAM 73 & 2.15 & 2.52 & 3.08 \\
\hline SED & 0.099 & & \\
\hline \multicolumn{4}{|l|}{ HI } \\
\hline 700256 & 32.9 & 32.8 & 31.0 \\
\hline BJ 104 & 37.2 & 35.9 & 38.2 \\
\hline EXBORNU & 28.7 & 30.6 & 28.7 \\
\hline GAM 73 & 30.9 & 31.3 & 30.1 \\
\hline SED & 0.80 & & \\
\hline \multicolumn{4}{|l|}{$\mathrm{CP}(\%)$} \\
\hline 700256 & 15.73 & 14.17 & 17.39 \\
\hline BJ 104 & 14.10 & 14.18 & 21.21 \\
\hline EXBORNU & 10.39 & 15.07 & 21.38 \\
\hline GAM 73 & 12.88 & 16.37 & 18.53 \\
\hline SED & 0.898 & & \\
\hline
\end{tabular}

in precipitation across the years and availability of residual soil N.

\subsection{On-farm trials}

Soil data analysis at different locations (Table 2) suggested that majority of soils were deficient in organic carbon (32-75\%), available phosphorous (41-97\%), available sulphur (22-77\%), available zinc (19-89\%) and available boron (36-87\%).

Precipitation data analysis at different locations revealed that 2010 was a normal precipitation year in all the districts whereas
Table 6

Effect of N fertilizer rates on Grain N uptake (GN uptake; $\mathrm{kg} \mathrm{ha}^{-1}$ ), Total aboveground $\mathrm{N}$ uptake (AGN uptake; $\mathrm{kg} \mathrm{ha}^{-1}$ ) and nitrogen harvest index (NHI) in pearl millet cultivars.

\begin{tabular}{lccc}
\hline \multirow{2}{*}{ Cultivar } & \multicolumn{2}{l}{ N applied $\left(\mathrm{kg} \mathrm{ha}^{-1}\right)$} & \\
\cline { 2 - 4 } & 0 & 20 & 40 \\
\hline GN uptake & & 32.1 & 42.9 \\
700256 & 45.2 & 34.3 & 65.0 \\
BJ 104 & 33.7 & 37.6 & 64.8 \\
EXBORNU & 21.3 & 40.6 & 48.9 \\
GAM 73 & 31.8 & & \\
SED & 4.19 & & 140.0 \\
AGN uptake & & 92.3 & 167.1 \\
700256 & 103.7 & 102.0 & 209.0 \\
BJ 104 & 92.8 & 121.7 & 167.0 \\
EXBORNU & 78.5 & 113.0 & \\
GAM 73 & 80.4 & & 33.46 \\
SED & 10.69 & & 43.06 \\
NHI & & 38.29 & 32.33 \\
700256 & 37.47 & 36.87 & 33.37 \\
BJ 104 & 40.66 & 33.81 & \\
EXBORNU & 28.90 & 35.12 & \\
GAM 73 & 34.02 & & \\
SED & 1.528 & & \\
\hline
\end{tabular}

growing season 2011 and 2012 were marked as dry years (Table 3). In 2011, precipitation was $8-30$ percent lower than the normal whereas in 2012 precipitation was $28-43$ percent lower than the normal precipitation. Crop yield was highly variable due to nonuniform distribution of precipitation across the locations and also across the seasons. Regression analysis showed that in less precipitation years, yield increment with the application of micronutrients linearly increased with seasonal precipitation as reported in growing season $2012\left(R^{2}=0.35\right)$, however in a good precipitation year grain yield decreased marginally with precipitation (Fig. 6).

\subsubsection{Effect of balanced nutrient application on pearl millet}

There was significant effect of location, fertilizer treatment and location $\times$ fertilizer on grain yield and AGDM (Table 8). In each growing season, grain yield and AGDM was significantly increased by improved practice (IP) where micronutrients were 
Table 7

Effect of $\mathrm{N}$ fertilizer rates on $\mathrm{N}$ uptake efficiency $(\mathrm{NUpE}=\mathrm{kg}$ aboveground dry matter $\mathrm{kg}$ soil available $\mathrm{N}^{-1}$ ), $\mathrm{N}$ Utilization efficiency ( $\mathrm{NUtE}=\mathrm{kg}$ grain yield $\mathrm{kg}$ above ground dry matter $\left.{ }^{-1}\right)$, physiological nitrogen use efficiency $(\mathrm{NUE}=\mathrm{NUpE} \times \mathrm{NUtE}=\mathrm{kg}$ grain yield soil available $\mathrm{N}^{-1}$ ) and agronomic nitrogen use efficiency $(\mathrm{AE}=$ (grain yield in fertilized plot-grain yield in unfertilized plot) fertilizer applied ${ }^{-1}$ ) in pearl millet cultivars.

\begin{tabular}{|c|c|c|c|}
\hline \multirow[t]{2}{*}{ Cultivar } & \multicolumn{3}{|c|}{$\mathrm{N}$ applied $\left(\mathrm{kg} \mathrm{ha}^{-1}\right)$} \\
\hline & 0 & 20 & 40 \\
\hline \multicolumn{4}{|l|}{ NUpE } \\
\hline 700256 & 1.09 & 0.83 & 1.06 \\
\hline BJ 104 & 1.08 & 0.95 & 1.28 \\
\hline EXBORNU & 0.99 & 1.16 & 1.62 \\
\hline GAM 73 & 0.84 & 1.01 & 1.26 \\
\hline SED & 0.089 & & \\
\hline \multicolumn{4}{|l|}{ NUtE } \\
\hline 700256 & 17.93 & 17.34 & 11.65 \\
\hline BJ 104 & 18.50 & 15.88 & 12.37 \\
\hline EXBORNU & 16.80 & 13.81 & 9.34 \\
\hline GAM 73 & 18.74 & 14.10 & 12.16 \\
\hline SED & 0.751 & & \\
\hline \multicolumn{4}{|l|}{ NUE } \\
\hline 700256 & 16.37 & 12.41 & 11.68 \\
\hline BJ 104 & 19.00 & 14.57 & 14.93 \\
\hline EXBORNU & 16.29 & 14.19 & 13.67 \\
\hline GAM 73 & 13.96 & 12.48 & 11.50 \\
\hline SED & 0.769 & & \\
\hline \multicolumn{4}{|l|}{$\mathbf{A E}$} \\
\hline 700256 & & 17.15 & 12.43 \\
\hline BJ 104 & & 18.30 & 13.42 \\
\hline EXBORNU & & 19.59 & 15.70 \\
\hline GAM 73 & & 18.73 & 15.65 \\
\hline SED & 2.88 & & \\
\hline
\end{tabular}

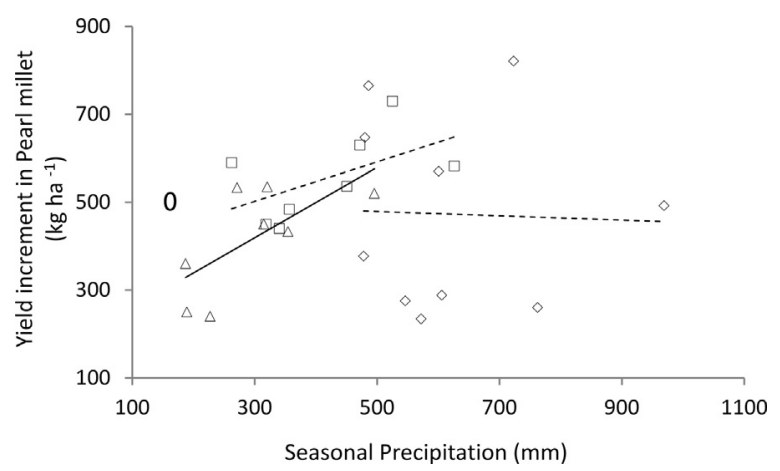

Fig. 6. Relationship between seasonal precipitation and pearl millet yield increase with balanced nutrient management in three seasons. Symbols represent years $\Delta=2010, \square=2011$ and $\Delta=2012$. Regression equations for three seasons 2010 $\left(y=-0.1828 x+647.87 ; R^{2}=0.008\right)$, year $2011\left(y=0.4489 x+367.21 ; R^{2}=0.30\right)$ and year $2012\left(y=0.8013 x+178.68 ; R^{2}=0.39\right)$. Solid lines represent statistically significant $(P=0.05)$ regression and dashed lines indicate regression was not significant.

applied along with major nutrients. Among the locations, significantly higher yields were recorded in Bijapur in 2010, Bagalkot in 2011 and Koppal district in 2012. There was an increase in grain yield of $17-28 \%$ in $2010,20-32 \%$ in 2011 and $25-32 \%$ in 2012. The effect of location on crop performance was confounded by farmer's management practice and cultivar grown. There was no benefit of balanced nutrition on partitioning of dry matter into grain so harvest index remained same under both treatments. Harvest index is more conservative trait which is associated with cultivar's genetic potential. Poor harvest index (24\%) in Yadgir in 2010 and Raichur in 2011 indicated severe drought stress in those regions. At some locations above ground dry matter was increased possibly in long duration cultivars but

Table 8

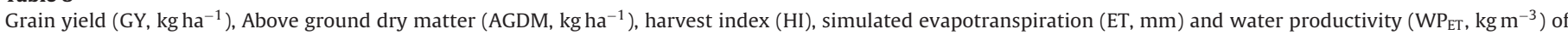

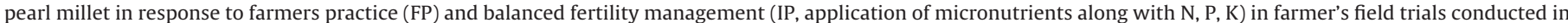
different districts of Karnataka.

\begin{tabular}{|c|c|c|c|c|c|c|c|c|c|c|}
\hline & \multirow{2}{*}{$\begin{array}{l}\text { Number of trials } \\
\text { (n) }\end{array}$} & \multicolumn{2}{|l|}{ GY } & \multicolumn{2}{|l|}{ AGDM } & \multicolumn{2}{|l|}{$\mathrm{HI}$} & \multirow[t]{2}{*}{ ET } & \multicolumn{2}{|l|}{$\mathrm{WP}_{\mathrm{ET}}$} \\
\hline & & $\mathrm{FP}$ & IP & $\mathrm{FP}$ & IP & $\mathrm{FP}$ & IP & & $\mathrm{FP}$ & IP \\
\hline \multicolumn{11}{|l|}{2010} \\
\hline Bijapur & 26 & 1960 & 2670 & 4560 & 6150 & 0.42 & 0.43 & 261 & 0.75 & 1.02 \\
\hline Gulbarga & 5 & 1590 & 2080 & 3850 & 4860 & 0.41 & 0.43 & 345 & 0.46 & 0.60 \\
\hline Raichur & 21 & 1260 & 1530 & 3220 & 3960 & 0.39 & 0.39 & 352 & 0.36 & 0.43 \\
\hline Yadagir & 18 & 1830 & 2525 & 7520 & 10,060 & 0.25 & 0.25 & 365 & 0.50 & 0.69 \\
\hline SED & & 263.3 & & 640.3 & & 0.022 & & & & \\
\hline$P$ (Location) & & $<0.001$ & & $<0.001$ & & $<0.001$ & & & & \\
\hline$P$ (Practice) & & $<0.001$ & & $<0.001$ & & 0.193 & & & & \\
\hline$P($ Loc $\times$ Prac $)$ & & $<0.001$ & & $<0.001$ & & 0.505 & & & & \\
\hline \multicolumn{11}{|l|}{2011} \\
\hline Bagalkot & 8 & 3230 & 4580 & 10,940 & 15,170 & 0.30 & 0.30 & 229 & 1.41 & 2.00 \\
\hline Bijapur & 10 & 1560 & 2050 & 3630 & 4610 & 0.43 & 0.45 & 214 & 0.73 & 0.73 \\
\hline Gulbarga & 10 & 1500 & 2170 & 3960 & 5605 & 0.38 & 0.39 & 270 & 0.56 & 0.80 \\
\hline Koppal & 5 & 920 & 1360 & 2580 & 4020 & 0.36 & 0.34 & 227 & 0.41 & 0.60 \\
\hline Raichur & 5 & 830 & 1040 & 3390 & 4290 & 0.24 & 0.24 & 269 & 0.31 & 0.39 \\
\hline Yadagir & 10 & 1690 & 2250 & 4040 & 5260 & 0.42 & 0.43 & 277 & 0.61 & 0.81 \\
\hline SED & & 324 & & 840 & & 0.0269 & & & & \\
\hline$P$ (Location) & & $<0.001$ & & $<0.001$ & & $<0.001$ & & & & \\
\hline$P$ (Practice) & & $<0.001$ & & $<0.001$ & & 0.072 & & & & \\
\hline$P($ Loc $\times$ Prac $)$ & & $<0.001$ & & $<0.001$ & & 0.131 & & & & \\
\hline \multicolumn{11}{|l|}{2012} \\
\hline Bellary & 10 & 820 & 1160 & 2370 & 3345 & 0.36 & 0.36 & 130 & 0.63 & 0.89 \\
\hline Bijapur & 10 & 1610 & 2150 & 3860 & 4990 & 0.40 & 0.42 & 190 & 0.85 & 1.13 \\
\hline Koppal & 10 & 1570 & 2280 & 4810 & 6820 & 0.34 & 0.34 & 189 & 0.83 & 1.21 \\
\hline Yadagir & 10 & 1450 & 1950 & 3870 & 5020 & 0.38 & 0.39 & 292 & 0.50 & 0.67 \\
\hline SED & & 209.7 & & 545.5 & & 0.035 & & & & \\
\hline$P$ (Location) & & $<0.001$ & & $<0.001$ & & 0.334 & & & & \\
\hline$P$ (Practice) & & $<0.001$ & & $<0.001$ & & 0.035 & & & & \\
\hline$P($ Loc $\times$ Prac $)$ & & 0.001 & & $<0.001$ & & 0.575 & & & & \\
\hline
\end{tabular}


Table 9

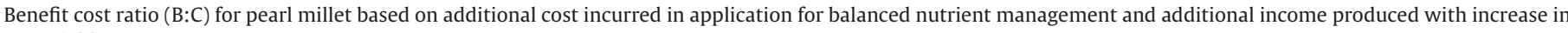
crop yield.

\begin{tabular}{|c|c|c|c|c|c|c|c|}
\hline \multirow[t]{2}{*}{ Location } & \multirow[t]{2}{*}{ Additional cost (INR) } & \multicolumn{3}{|c|}{ Additional benefit (INR) } & \multicolumn{3}{|l|}{$\mathrm{B}: \mathrm{C}$} \\
\hline & & 2010 & 2011 & 2012 & 2010 & 2011 & 2012 \\
\hline Banglkot & 1625 & & 11,871 & & & 6.31 & \\
\hline Bellary & 1027 & & & 9515 & & & 8.27 \\
\hline Bijapur & 1375 & 5955 & 4312 & 5292 & 3.33 & 2.14 & 2.85 \\
\hline Gulberga & 1625 & 4536 & 5896 & & 1.79 & 2.63 & \\
\hline Koppal & 1425 & & 3872 & 7056 & & 1.72 & 3.95 \\
\hline Raichur & 1625 & 2268 & 1848 & & 0.40 & 0.14 & \\
\hline Yadgir & 1625 & 5838 & 4919 & 4900 & 2.59 & 2.03 & 2.02 \\
\hline
\end{tabular}

this did not result in increased grain yield because additional dry matter was partitioned to stem rather than panicle growth. Application of micronutrients resulted in improved water productivity in pearl millet. Benefit:cost ratio varied across the locations depending upon agro-climatic conditions, amount of fertilizer used and yield levels in the location. B:C ratios varied from 1.72 to 8.27 across the locations and indicated that additional cost on application of balanced nutrient management is justified by additional benefits gained through increase in grain yield even in dry seasons of 2011 and 2012. Raichur had lowest B:C ratio when crop suffered extreme stress (Table 9).

\section{Discussion}

\subsection{Effect of balanced nutrition application on pearl millet}

Very few on-farm studies on balanced nutrition of pear millet under limited water conditions exist. Soil data analysis from farmer's field suggested that crop yields are limited because of low soil fertility levels. As micronutrients deficiency has implications for plant metabolism, therefore pearl millet responded even to the small amounts of micronutrients applications. Here we report improved grain yields of pearl millet even in dry years with balanced nutrient management which provides resilience against drought. Firstly, uptake of nutrients is affected even if one nutrient is limiting e.g. interdependence of $\mathrm{N}$ with $\mathrm{S}$ and $\mathrm{Zn}$ metabolism. It is well documented now that nitrogen uptake and assimilation increases with sulphur availability (Zhao et al., 1999) and N fertilization combined with soil and/or foliar Zn applications, has a synergistic positive effect on grain $\mathrm{Zn}$ concentration (Kutman et al., 2011; Cakmak et al., 2010). Nitrogen application increase mineral uptake so grain concentrations increase for $\mathrm{Fe}, \mathrm{Cu}, \mathrm{Mg}$ and $\mathrm{Zn}$ (Gooding et al., 2012b). Secondly, damage caused by limited water at early growth stages is compensated by plant nutrient availability. Thirdly, fertilized millet suffers less during water shortage at panicle initiation and at grain filling compared to non-fertilized millet (Rockstorm and de Rouw, 1997). We report that yield increase in dry years with micronutrient application was due to improvement in water productivity. Earlier Girish et al. (2012) also reported that application of micronutrients improves water productivity in crops.

Rainfed systems are highly vulnerable to various types of climatic and socio-economic shocks. Extreme climatic events and depleting soil fertility not only affect crop productivity but often leads to crop failures in the region. With the climate change, frequency of extreme climatic events in terms of changing precipitation patterns and increasing temperature are expected to increase (IPCC, 2007), therefore it is important to evaluate the crops and cropping systems in SAT for their resilience against fragile environments. Resilience is the capacity of a system to absorb disturbance and still retain its basic function and structure (Walker and Salt, 2006). Although the purpose of this study is to evaluate the performance of pearl millet with balanced nutrient management; however two dry seasons 2011 and 2012 provided an opportunity to see the resilience of pearl millet to the drought. Despite $42 \%$ deficit rainfall in 2012, we found the yield increase from 25 to $31 \%$ with balanced nutrient management compared to farmers practice. Pearl millet responds to climatic variables however yield penalty is less than other cereals (Sorghum, Maize) and legumes (Soybean) and when nutrients are applied adequately.

Under low productivity conditions such as marginal soils, erratic precipitation and low credits for purchasing fertilizers in SAT, it is pertinent to evaluate the sustainability and profitability of the technology for a given set of agro-climatic conditions. Farmer's acceptability for any technology is driven by the ability of the system to provide economic security. Benefit:cost analysis showed that balanced nutrient management of pearl millet is economically viable across the years and locations except for Raichur. Therefore, pearl millet can be an important component of cropping systems in low production conditions with improved agronomic management.

\subsection{Effect of season on crop yield}

There is large intra seasonal precipitation variability with no significant change in annual precipitation over a period of 1981-1995 (Rao and Wani, 2011). Intra seasonal distribution of precipitation has stronger effect on crop growth than fluctuations in annual precipitation. The variation in pearl millet yield was related to the precipitation distribution within season, with dry and wet spells being key determinants of crop yield. The precipitation unpredictability is a major constraint to plan the start of cropping season (Pieri, 1989) as dry spells during early crop growth stages may result in poor establishment or germination. Our results suggest that there is uncertainty in uniform distribution of precipitation in June which represents the land preparation period which consequently may delay planting date and reduce length of crop cycle. Pearl millet yield variability in SAT is often related with water shortage during crop season however, we found a negative effect of seasonal precipitation and September precipitation on pearl millet grain yield. Our results confirm that wet spells also have detrimental effect on crop yield if it coincides with anthesis and grain filling/physiological maturity. Heavy precipitations at anthesis resulted in pollen washing leading to poor seed setting. Crop lodging due to heavy precipitations at physiological maturity and incidence of ergot due to high humidity contributed to lower yields in wet years. Our results confirm that excessive precipitation in September results in excess runoff and water logging conditions in shallow soils with low water holding capacity. Secondly, decline in grain yield even in seasons with high rainfall may be because of soil degradation and reduction in rainfall effectiveness. Lal (2010) reported that yield potential of elite varieties is not realized in marginal soils of SAT.

Consistent with Maman et al. (1999) we found that seasonal variability had a greater effect on yield and $\mathrm{N}$ levels than cultivars and applied N. In dry years crop yield is affected due to water 
stress, however in wet years although water stress was minimal but yield declined due to excessive runoff. During dry years crop utilize water more efficiently resulting in higher water productivity. During dry years, crop yields were comparable to normal years because delay in flowering and then buffering by tillers provides an adaptive mechanism overcome drought in pearl millet (Mahalakshmi and Bidinger, 1985).

This study showed a positive effect of August maximum temperature which coincides with anthesis and grain filling on pearl millet yield. Earlier work by Ong (1983) reported that early reproductive stage is sensitive to increased temperatures whereas late reproductive or grain filling phase are less affected with increasing temperature and a mean temperature of $30.5 \pm 2.5^{\circ} \mathrm{C}$ is optimum for anthesis. During our study period august maximum temperature seldom exceed $32^{\circ} \mathrm{C}$ therefore leading to positive relation with grain yield as temperature exceed from 28 to $30.5^{\circ} \mathrm{C}$. Besides that each cultivar has its threshold limit for temperature tolerance e.g. drought tolerant summer cultivars 86M64, 9444 and GHB 558 can tolerate temperature as high as $42^{\circ} \mathrm{C}$ (Yadav et al., 2012; K N Rai, through personal communication). Pearl millet varieties have different threshold limits for temperature; $35^{\circ} \mathrm{C}$ for temperature sensitive and $42^{\circ} \mathrm{C}$ for tolerant varieties (Estibaliz Leibar and Vincent Vadez, through personal communication). Increasing temperature adversely affect grain number and reduce grain yield however some hybrids e.g. ICMB 05666 can have $>60 \%$ seed setting at $42{ }^{\circ} \mathrm{C}$ when coupled with water availability (Yadav et al., 2012). In pearl millet, a variation in the value of optimum temperature would be more significant to reduce the risk of damage due to high temperature in millet growing regions.

\subsection{Genotypic variation for NUE}

Present results showed genetic variation in NUE was more closely associated with NUtE than NUpE under both low and high $\mathrm{N}$ conditions therefore former contribute more towards cultivar's yielding ability. Several investigators worldwide indicated that NUpE accounts for a greater proportion of genetic variation in NUE at low N supply in cereals (Barraclogh et al., 2010; Kutman et al., 2011; Ortiz-Monasterio et al., 1997; Le Gouis et al., 2000). The present results are consistent with Barraclogh et al. (2010) who observed that NUtE was the key component determining genetic variation in grain yield under low, intermediate or high $\mathrm{N}$ conditions. Our results are consistent with (Alagarswamy and Bidinger, 1982) that pearl millet cultivars did not differ in nitrogen uptake but did differ in their ability to use nitrogen. The usefulness of such genotypic variability can be exploited in both low and high fertility conditions for optimizing both grain yield and NUE. We found that improvements in grain yield were more closely associated with grain $\mathrm{N}$ uptake than above ground $\mathrm{N}$ uptake. This suggests traits favouring high grain $\mathrm{N}$ uptake could be a potential target for breeding for improved grain yield under low and moderate $\mathrm{N}$ supply in pearl millet. Here we used $40 \mathrm{~kg} \mathrm{~N} \mathrm{ha}^{-1}$ as optimum fertilizer rate for pearl millet production in SAT whereas it responds to higher fertilizer rates as reported by many authors. Consistent with other authors (Alagarswamy and Bidinger, 1987; Maman et al., 1999) we found that NUE decreases as the $\mathrm{N}$ rate increases which has implications on environment. $\mathrm{N}$ fertilizer application increased pearl millet grain yield and crude protein and $\mathrm{N}$ in vegetative tissues. Increase in crude protein concentration over the years may be due to building of organic $\mathrm{C}$ with residue incorporation and $\mathrm{N}$ application. It has been reported earlier that long-term application of $\mathrm{N}$ fertilizer at the optimum levels sustains yields and improves soil quality by increasing Carbon sequestration (Wani et al., 2007).

In low input production environments under limited $\mathrm{N}$ supply, cultivars that use nitrogen more efficiently are a sustainable solution to increase crop yield in these systems. Genotypic variation in nitrogen use efficiency in pearl millet landraces under low production environments and marginal soils may therefore represent a source of variation for development of varieties adapted to low fertilizer input cropping systems.

\section{Conclusion}

Balanced nutrient application improves pearl millet productivity on farmers' field which were critically deficient in macroand micronutrients. Application of balanced nutrient provides resilience against drought by improving grain yield in dry seasons through enhanced water productivity. Additional cost on application of balanced nutrient management is justified by additional benefits gained through increase in grain yield even in dry seasons. Pearl millet yield was positively associated with August maximum temperature and negatively with seasonal precipitation. September precipitation $>125 \mathrm{~mm}$ which coincided with grain filling stage reduced grain yield in marginal soils. Except wet years, crop yields were comparable in dry and normal seasons which indicate pearl millet's genetic pre-disposition to perform under drought and its production is still advantageous in this region. Ability of pearl millet to ensure grain production even under low fertility and high temperature conditions provides resilience under climate change however higher yields can be achieved with improved agronomic management.

\section{Acknowledgements}

The authors are grateful to Dr Peter J Dart for planning this experiment and Mr Babu Rao for technical assistance. Late Dr F.R. Bidinger had an instrumental role in executing this experiment and authors acknowledge his contributions in this experiment.

\section{References}

Alagarswamy, G., Bidinger, F.R., 1982. Nitrogen uptake and utilization by [pearl millet (Pennisetum americanum (L.) Leeke]. In: 9th International Plant Nutrition Congress, Warwick University, UK. 22-27 August 1982.

Alagarswamy, G., Bidinger, F.R., 1987. Genotypic variation in biomass production and nitrogen use efficiency in pearl millet (Pennisetum americanum (L.) Leeke] Genetic Aspects Plant Miner. Nutr. Dev. Plant Soil Sci. 27, 282-286.

Allen, R.G., Pereira, L.S., Smith, M., Raes, D., Wright, J.L., 2005. FAO-56: dual crop coefficient method for estimating evaporation from soil and application extensions. J. Irrig. Drain. Eng. 1, 10.1061/(ASCE)0733-9437(2005)131.

Barraclogh, P.B., Howarth, J.R., Jones, J., Lopez-Bellido, R., Parmar, S., Shepherd, C.E. Hawkesford, M.J., 2010. Nitrogen efficiency of wheat: genotype and environmental variation and prospects for improvement. Eur. J. Agron. 33, 1-33.

Bidinger, F.R., Weltzien, R.E., Mahalakhsmi, V., Singh, S.D., Rao, K.P., 1994. Evaluation of landrace top cross hybrids of pearl millet for arid zone environments. Euphytica 76, 215-226.

Cakmak, I., Pfeiffer, W.H., McClafferty, B., 2010. Biofortification of durum wheat with zinc and iron. Cereal Chem. 87, 10-20.

Chevalier, P., Schrader, L.E., 1977. Genotypic differences in nitrate absorption and partitioning of $\mathrm{N}$ among plant parts in maize. Crop Sci. 17, 897-901.

Cox, M.C., Qualset, C.O., William, R.D., 1985. Genetic variation for nitrogen assimilation and translocation in wheat. I. Dry matter and nitrogen accumulation. Crop Sci. $25,430-435$.

Fazli, I.S., Jamal, A., Ahmad, S., Masoodi, M., Khan, J.S., Abdin, M.Z., 2008. Interactive effect of sulphur and nitrogen on nitrogen accumulation and harvest in oilseed crops differing in nitrogen assimilation potential. J. Plant Nutr. 31, 1203-1220.

Garg, K.K., Bharati, L., Gaur, A., George, B., Acharya, S., Jella, K., Narasimhan, B., 2012 Spatial mapping of agricultural water productivity using SWAT model in upper Bhima catchment, India. Irrig. Drain. 61, 60-79.

Garg, K.K., Wani, S.P., Rao, A.V.R.K., 2013. Crop coefficients of Jatropha (Jatropha curcas) and Pongamia (Pongamia Pinnata) using water balance approach. WIREs: Energy Environ., DOI 10.1002/wene.88.

Gascho, G.J., Menezes, R.S.C., Hanna, W.W., Hubbard, R.K., Wilson, J.P., 1995. Nutrient requirements of pearl millet. In: Proceedings First National Grain Pearl Millet Symposium, 17-18 January, Georgia.

Girish, C., Wani, S.P., Sahrawat, K.L., Jangwad, L.S., 2012. Balanced plant nutrition enhances rainfed crop yields and water productivity in Jharkhand and Madhya Pradesh states of India. J. Trop. Agric. 50, 24-29.

Gooding, M.J., Addisu, M., Uppal, R.K., Snape, J.W., Jones, H.E., 2012a. Effect of wheat dwarfing genes on nitrogen-use efficiency. J. Agric. Sci. 150, 3-22. 
Gooding, M.J., Fan, M., McGrath, S.P., Shrewy, P.,Zhao, F.J., 2012b. Contrasting effects of dwarfing alleles and nitrogen availability on mineral concentrations in wheat grain. Plant Soil 360, 93-107.

IPCC, 2007. Climate Change 2007. The Physical Science Basis, Contribution of Working Group I to the Fourth Assessment Report of the Intergovernmental Panel on Climate Change. Cambridge University Press, Cambridge, UK, pp. 996.

Joshi, N.L., Kalla, J.C., 1986. Economising nitrogen use of pearl millet in the Indian Arid zone. Annals Arid Zone 25, 321-325.

Kindred, D.R., Gooding, M.J., 2004. Heterotic and seed rate effects on nitrogen efficiencies in wheat. J. Agric Sci. 142, 639-657.

Kutman, U.B., Yildiz, B., Cakmak, I., 2011. Effect of nitrogen on uptake, remobilization and partitioning of zinc and iron throughout the development of durum wheat. Plant Soil 342, 149-164.

Lal, R., 2010. Enhancing eco-efficiency in agro-ecosystems through soil carbon sequestration. Crop Sci. 50, 120-131.

Le Gouis, J., Beghin, D., Heumez, E., Pluchard, P., 2000. Genetic differences for nitrogen uptake and nitrogen utilization efficiencies in winter wheat. Europ. J. Agron. $12,163-173$

Mahalakshmi, V., Bidinger, F.R., 1985. Flowering response of pearl millet to wate stress during panicle development. Annals Appl. Biol. 106, 571-578.

Maman, N., Mason, S.C., Galusha, T., Clegg, M.D., 1999. Hybrid and nitrogen influence on pearlmillet production in Nebraska: yield, growth, and nitrogen uptake and nitrogen use efficiency. Agron. J. 91, 737-743.

Maranville, J.W., Clark, R.B., Ross, W.M., 1980. Nitrogen efficiency in grain sorghum. J. Plant Nutr. 2, 577-589.

Mousavi, S.R., 2011. Zinc in crop production and interaction with phosphorus. Aus J. Basic Appl. Sci. 5, 1503-1509.

Moll, R.H., Kamprath, E.J., Jackson, W.A., 1982. Analysis and interpretation of factors which contribute to efficiency to nitrogen utilization. Agron. J. 74, 562-564.

O'Leary, G.J., Joshi, N.L., van Oosterom, E.J., 2008. A simulation study of the response of plant-type and nitrogen fertilization on the grain yield of pearl millet. Annals Arid Zone 47, 121-137.

Ong, C.K., 1983. Response to temperature in a stand of pearl millet (Pennisetum typhoides, S \& H). 2. Reproductive development. J. Exp. Bot. 34, 337-348.

Ong, C.K., Monteith, J.L., 1985. Response of pearl millet to light and temperature. Field Crops Res. 11, 141-160.

Ortiz-Monasterio, J.I., Sayre, K.D., Rajaram, S., McMahom, M., 1997. Genetic progress in wheat yield and nitrogen use efficiency under four nitrogen rates. Crop Sci. 37, 898-904.

Pieri, C., 1989. Fertilité des terres de savanes. Bilan de trente ans de recherche et de développement agricoles au sud du Sahara, p. 443.

Pyne, W.A., Drew, M.C., Hossner, L.R., Lascano, R.J., Onken, A.B., Wendt, C.W., 1992. Soil phosphorous availability and pearl millet water-use efficiency. Crop Sci. 32 1010-1015.
Rai, K.N., Rao, A.S., 1991. Effect of d2 dwarfing gene on grain yield and yield components in pearl millet near-isogenic lines. Euphytica 52, 25-31.

Rao, A.V.R.K., Wani, S.P., 2011. Evapotranspiration paradox at a semi-arid location in India. J. Agrometeorol. 13, 3-8.

Rockstorm, J., de Rouw, A., 1997. Water, nutrients and slope position in on-farm pearl millet cultivation in Sahel. Plant Soil 195, 311-327.

Saharawat, K.L., Wani, S.P., 2013. Soil testing as a tool for on-farm productivity management: experience from the semi-arid zone of India. Comm. Soil Sci. Plant Anal. 44, 1011-1032.

Singh, R.S., Joshi, N.L., Singh, H.P., 1998. Pearl millet phenology and growth in relation to thermal time under arid environment. J. Agron. Crop Sci. 183, 83-91.

Tuong, T.P., Bouman, B.A.M., 2003. Rice production in water-scarce environments, In: Kijne, J.W., Barker, R., Molden, D. (Eds.), Water Productivity in Agriculture: Limits and Opportunities for Improvement. CABI Publishing, Wallingford, UK, pp. 53-67.

Walker, B., Salt, D., 2006. Resilience Thinking. Sustaining Ecosystems and People in a Changing World. Island Press, pp. 1-174.

Wani, S.P., Zambre, M.A., Lee, K.K., 1990. Genotypic diversity in pearl millet (Pennisetum glaucum) for nitrogen, phosphorous and potassium use efficiencies. J. Plant Nutr., 595-601.

Wani, S.P., Sahrawat, K.L., Sreedevi, T.K., Bhattacharyya, T., Srinivasa, R.C., 2007. Carbon sequestration in the semi-arid tropics for improving livelihoods. International J. Environ. Studies 64, 719-727.

Wani, S.P., Sreedevi, T.K., Rockstorm, J., Ramakrishna, Y. S, 2009. Rainfed agriculturePast trend and future prospects. In: Wani, S.P., Rockstorm, J., Oweis, T. (Eds.), Rainfed Agriculture: Unlocking the Potential. Comprehensive Assessment of Water Management in Agriculture Series. CAB International, Wallingford, UK, pp. 1-35.

Wani, S.P., Rockstorm, J., Venkateswarlu, B., Singh, A.K., 2011. New paradigm to unlock the potential of rainfed agriculture in the semi-arid tropics. In: Lal, R. Stewart, B.A. (Eds.), World Soil Resources and Food Security. CRC Press, UK, pp. 419-470.

Wani, S.P., Garg, K.K., Singh, A.K., Rockstrom, J., 2012. Sustainable management of scarce water resources in tropical rainfed agriculture. In: Lal, R. Stewart, B.A. (Eds.), Advances in Soil Science: Soil Water and Agronomic Productivity. CRC Press, UK, pp. 347-408.

Yadav, O.P., Rai, K.N., Gupta, S.K., 2012. Pearl millet: genetic improvement for tolerance to abiotic stress. In: Tuteja, N., Gill, S.S., Tuteja, R. (Eds.), Improving Crop Productivity in Sustainable Agriculture.

Zhao, F.J., Hawkesford, M.J., McGrath, S.P., 1999. Sulphur assimilation and effects on yield and quality of wheat. J. Cereal Sci. 30, 1-17. 